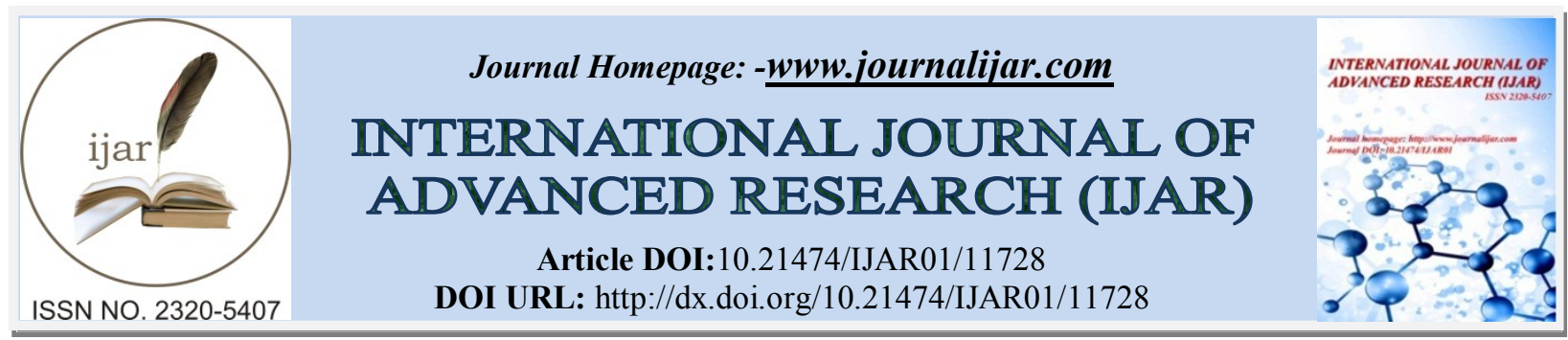

RESEARCH ARTICLE

\title{
A CASE OF VIBRIO CHOLERAE MENINGITIS IN A NEONATE
}

Dr. Mohit Tyagi, Dr. Saroja Balan and Dr. Vidya Gupta

Department of Neonatology, Indraprastha Apollo Hospital, Delhi,India.

\section{Manuscript Info}

Manuscript History

Received: 15 July 2020

Final Accepted: 18 August 2020

Published: September 2020

\begin{abstract}
Bacteraemia resulting due to vibrio cholera can lead to invasive disease such as septicemia and meningitis in the neonatal age group especially in immunosuppressed population. Vibrio cholera is known to cause diarrhoeal illness in adults and children but very rarely, it causes infection in neonates. We report a case of septicemia with meningitis due to vibrio cholera in a neonate at Indraprastha Apollo Hospital (IAH), New Delhi.

Copy Right, IJAR, 2020,. All rights reserved.
\end{abstract}

\section{Introduction:-}

Bacteraemia resulting due to vibrio cholera can lead to invasive disease such as septicemia and meningitis in the neonatal age group especially in immunosuppressed population. Vibrio cholera is known to cause diarrhoeal illness in adults and children but very rarely, it causes infection in neonates. We report a case of septicemia with meningitis due to vibrio cholera in a neonate at Indraprastha Apollo Hospital (IAH), New Delhi.

\section{Case Report:}

A 28-days-old male neonate, born by lower segment caesarean section (LSCS) to a multigravida (G3P2L1A1) mother, was admitted at IAH. Baby weighed 2.9 kilogram $(\mathrm{kg})$ at birth. There was no immediate postnatalcomplication. Baby was discharged homeon day 3 of life and remained asymptomatic thereafter.On Day $28^{\text {th }}$ of life, baby developed fever, for which baby received symptomatic treatment. On day $30^{\text {th }}$ of life, baby hadsudden onset of tonic convulsions. IV midazolamand one dose of IV Meropenam and vancomycin was given and referred to IAH for further management. There was no history of diarrhoea and vomiting. On arrival at Emergency, baby was in status epilepticus. Baby was loaded with injection Phenobarbitone, stabilised and shifted to neonatal intensive care unit (NICU).

On initial examination, baby was afebrile (Temp- $37.0^{\circ} \mathrm{C}$ ), heart rate was 180 beats per minute with respiratory rate was 46 breaths per minute and $92 \%$ saturation on oxygen by nasal prongs @ 2litres $/ \mathrm{min}$. Capillary refilling time was delayed $(>4 \mathrm{sec})$ with cold extremities and poor peripheral pulsations.The anterior fontanel was bulging with increased tone in all four limbs with pin-point pupils, sluggishly reacting to light.The relevant blood investigations were sent. Clinical diagnosis of meningitis was made and baby was started on IV Meropenam, IV Vancomycin. The complete blood count revealed a normal white cell count (TLC- $8.8 \times 10^{3} / \mathrm{mm}^{3}$ ) with thrombocytopenia (1.19 lac/ $\mathrm{mm}^{3}$ ).C-reactive protein was positive (73.6). Blood culture was sterile. The cerebrospinal fluid (CSF) done showed leucocytosis (TLC- 240), protein level of $984 \mathrm{mg} / \mathrm{dl}$ with glucose of $17 \mathrm{mg} / \mathrm{dl}$ (corresponding to lab blood sugar was $69 \mathrm{mg} / \mathrm{dl}$ ). After an incubation period of 24 hours, CSF culture yielded rod shaped gram negative bacteria, V. cholera. Slide agglutination tests were negative for O1 and 0139 antigens. IVantibiotics were changed to Ciprofloxacin with Meropenemaccording to their sensitivity report. Rapid Meningitis/encephalitis molecular array panel (Bio Fire Diagnostics, USA) was also done on CSF was negative. Stool and urine routine reports were also normal. 
During the hospital course, baby's activity was poor with marked respiratory depression. Baby was electively ventilated and started on Dopamine infusion. Thedopamine was tapered in next $48 \mathrm{hrs}$ and stopped as the blood pressure and other vital signs improved.Ultrasonography (USG) cranium done showed increased reflectivity of meninges in both hemispheres with no intracranialbleed. As baby continued to have tonic convulsions even after the full dose of phenobarbitone, levetiracetam was added. Despite adding levetiracetam convulsions continued and midazolam infusion started and titrated.

MRI Brain done on day 3 of admission, revealed bleed in bilateral frontal andthalamo-capsular region, intraventricular bleed with bright signal from splenium/genu of corpus callosum suggestive of acute demyelination.Repeat USG cranium done after 72 hours of hospital stay showed extensive bleed with cerebral oedema, so inj. Dexamethasone was also added.As baby developed signs of raised intracranial pressure, mannitol was started.

As baby continued to deteriorate, parents were counselled regarding guarded prognosis and poor neurological outcome. His parents opted to take the baby home, against medical advice (LAMA). Later baby died after few days.

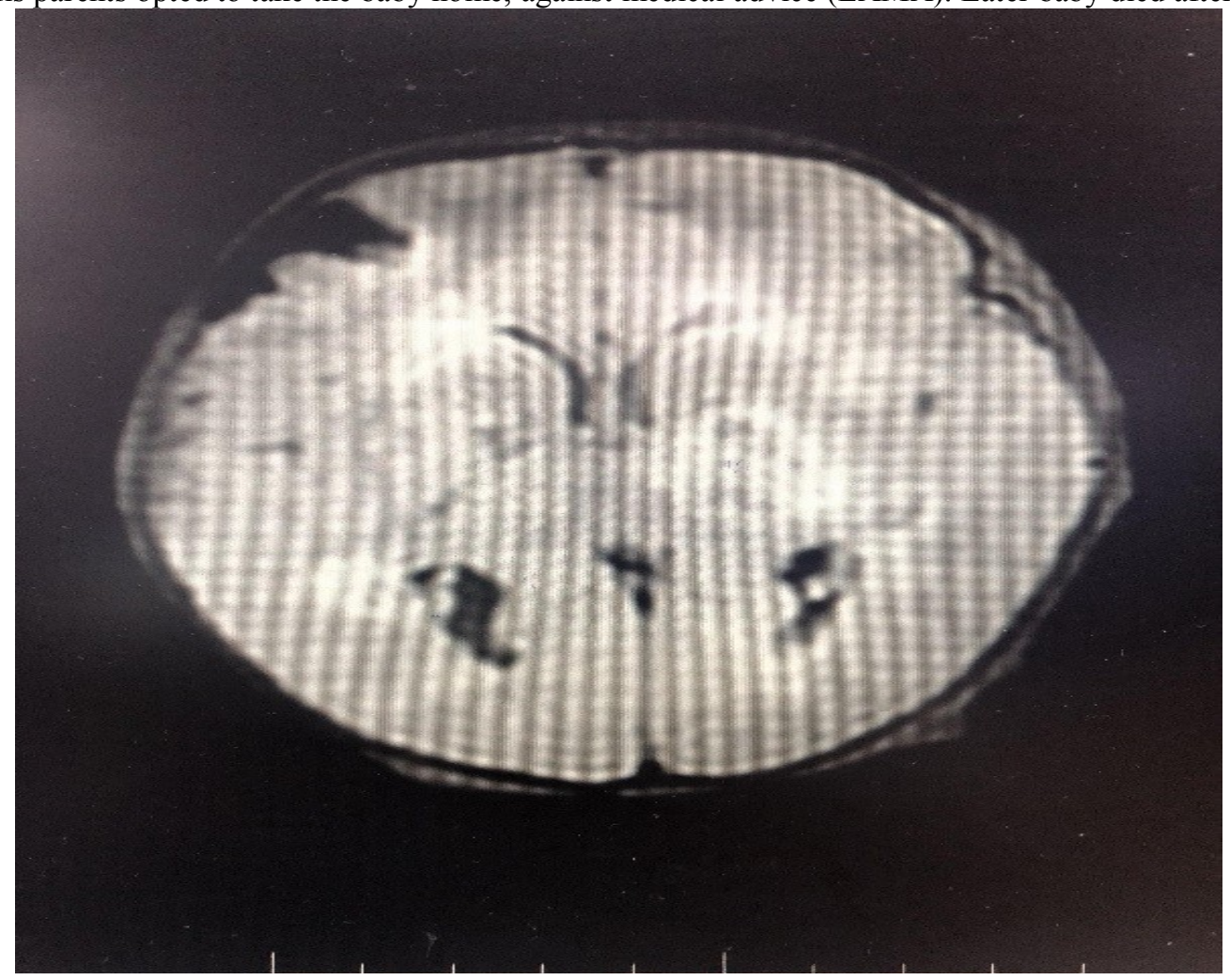

MRI Brain done, revealed bleed in bilateral frontal, bilateral thalamo capsular region and intraventricular bleed with bright signal from splenium/Genu of corpus callosum suggestive of acute demyelination

\section{Discussion:-}

Septicaemia by V. cholera is a rare but life threatening condition, particularly in infants [1]. To the best of our knowledge, so far only 7 case reports of infants who developed septicaemia due to V. Cholerae (non -O1/non O139 V). From these case reports we came to conclude that, v. Cholerae is associated with a very high rate of meningitis with poor prognosis. Four patients were diedand threepatients have survived with neurological sequelae.

Non-01, non-0139 Vibrio cholera bacteremia reported in recent English literature 


\begin{tabular}{|c|c|c|c|c|c|c|c|c|}
\hline Study & $\begin{array}{l}\text { Regi } \\
\text { on }\end{array}$ & Age & $\begin{array}{l}\text { Gen } \\
\text { der }\end{array}$ & $\begin{array}{l}\text { Underlying } \\
\text { pathology/com } \\
\text { orbidity }\end{array}$ & $\begin{array}{l}\text { Suspecte } \\
\mathrm{d} \text { source }\end{array}$ & Clinical features & $\mathrm{T} / \mathrm{T}$ & Outcome \\
\hline $\begin{array}{l}\text { Rubi } \\
\mathrm{n} \quad \text { et } \\
\text { al,19 } \\
81\end{array}$ & USA & $\begin{array}{l}3 \\
\text { wee } \\
\text { ks }\end{array}$ & & & $\begin{array}{l}\text { Infant's } \\
\text { bottle } \\
\text { was kept } \\
\text { in a } \\
\text { container } \\
\text { of live } \\
\text { carbs }\end{array}$ & $\begin{array}{l}\text { Bacteraemia, } \\
\text { Meningitis }\end{array}$ & $\begin{array}{l}\text { Ampicillin, } \\
\text { Gentamicin }\end{array}$ & $\begin{array}{l}\text { Severely } \\
\text { neurologic } \\
\text { ally } \\
\text { impaired at } \\
6 \text { months }\end{array}$ \\
\hline $\begin{array}{l}\text { Naid } \\
\mathrm{u} \text { et } \\
\text { al,19 } \\
93\end{array}$ & USA & $\begin{array}{l}6 \\
\text { wee } \\
\text { ks }\end{array}$ & $\mathrm{M}$ & & $\begin{array}{l}\text { Fish was } \\
\text { cleaned } \\
\text { in same } \\
\text { sink, } \\
\text { where } \\
\text { baby } \\
\text { bathed }\end{array}$ & $\begin{array}{l}\text { Bacteraemia, } \\
\text { Meningitis }\end{array}$ & $\begin{array}{l}\text { Ampicillin, } \\
\text { Gentamicin }\end{array}$ & Death \\
\hline $\begin{array}{l}\text { Ismai } \\
1 \text { et } \\
\text { al, } \\
2017\end{array}$ & $\begin{array}{l}\text { Kuw } \\
\text { ait }\end{array}$ & $\begin{array}{l}60 \\
\text { hour } \\
\text { s }\end{array}$ & $\mathrm{M}$ & $\begin{array}{l}\text { Prematutebaby, } \\
\text { low birth } \\
\text { weight }\end{array}$ & $\begin{array}{l}\text { Mother } \\
\text { consume } \\
\mathrm{d} \text { fish in } \\
\text { week } \\
\text { before } \\
\text { delivery }\end{array}$ & $\begin{array}{l}\text { Septicemia,Meni } \\
\text { ngitis, } \\
\text { Cerebralabscess, } \\
\text { unilateral } \\
\text { hydrocephalous }\end{array}$ & $\begin{array}{l}\text { Ampicillin, } \\
\text { Cefotaxime }\end{array}$ & $\begin{array}{l}\text { Discharged } \\
\text { on Day } 24 \\
\text { of life,as } \\
\text { neurologic } \\
\text { al } \\
\text { examinatio } \\
\text { n was } \\
\text { unremarka } \\
\text { ble but } \\
\text { developed } \\
\text { cardiorespi } \\
\text { ratory } \\
\text { arrest and } \\
\text { died. }\end{array}$ \\
\hline $\begin{array}{l}\text { Kerk } \\
\text { etta } \\
\text { et al, } \\
2002\end{array}$ & India & $\begin{array}{l}10 \\
\text { days }\end{array}$ & $\mathrm{M}$ & & $\begin{array}{l}\text { Cow's } \\
\text { milk }\end{array}$ & $\begin{array}{l}\text { Septicemia,Meni } \\
\text { ngitis }\end{array}$ & $\begin{array}{l}\text { Ampicillin, } \\
\text { Cefotaxime }\end{array}$ & $\begin{array}{l}\text { Left } \\
\text { against } \\
\text { medical } \\
\text { advice,con } \\
\text { dition } \\
\text { improved }\end{array}$ \\
\hline $\begin{array}{l}\text { Hao } \\
\text { et } \\
\text { al,20 } \\
15\end{array}$ & $\begin{array}{l}\text { Chin } \\
\text { a }\end{array}$ & $\begin{array}{l}11 \\
\text { days }\end{array}$ & $\mathrm{F}$ & & $\begin{array}{l}\text { Contami } \\
\text { nated } \\
\text { food and } \\
\text { Parapher } \\
\text { nalia }\end{array}$ & $\begin{array}{l}\text { Septecemia, } \\
\text { Meningitis }\end{array}$ & $\begin{array}{l}\text { Sulbenicillin,Metr } \\
\text { onidazole }\end{array}$ & $\begin{array}{l}\text { Resolved } \\
\text { with some } \\
\text { neurologic } \\
\text { al deficits }\end{array}$ \\
\hline $\begin{array}{l}\text { Sarw } \\
\text { ar et } \\
\text { al,20 } \\
15\end{array}$ & $\begin{array}{l}\text { Pakis } \\
\tan \end{array}$ & $\begin{array}{l}3 \\
\text { days }\end{array}$ & $\mathrm{M}$ & $\begin{array}{l}\text { Very low birth } \\
\text { weight }\end{array}$ & $\begin{array}{l}\text { Goat's } \\
\text { Milk }\end{array}$ & Bacteraemia & Metronidazole & $\begin{array}{l}\text { Neurologic } \\
\text { al deficits, } \\
\text { Death after } \\
15 \text { days }\end{array}$ \\
\hline $\begin{array}{l}\text { Mirz } \\
\text { a } \\
\text { Zain } \\
\text { et } \\
\text { al,20 } \\
18 \\
\end{array}$ & $\begin{array}{l}\text { Pakis } \\
\tan \end{array}$ & $\begin{array}{l}2 \\
\text { mon } \\
\text { ths }\end{array}$ & $\mathrm{M}$ & & & $\begin{array}{l}\text { Bacteremia,abdo } \\
\text { minal distension, } \\
\text { B/l lamellar } \\
\text { cataract,jaundice, } \\
\text { hepato- } \\
\text { splenomegaly }\end{array}$ & $\begin{array}{l}\text { Cefotaxime,Amik } \\
\text { acin }\end{array}$ & Death \\
\hline
\end{tabular}

Infection with Vibrio cholerae usually arise from water sources. In our case, we were not able to ascertain, the source of infection as he was delivered by caesarean section, so perinatal acquisition of organism from vaginal or 
faecal flora was unlikely. Since the baby was on top feeds/ bottle feeding, acquisition of vibrio cholera organism was most likely through contaminated water source. Interestinglydiarrhoea was absent in all of the infants reported earlier cases and in our case too. Vibrio cholerae non 0:1 is widespread throughout India and can cause serious systemic disease in very young infants or neonates with underlying disease. Therefore, vibrio cholera should be considered in the differential diagnosis of bacteraemia and meningitis in neonates especially in the developed world where water source may be contaminated.

It is therefore imperative that early diagnosis be made and early intervention in the form of intravenous antibiotics should be started. Unlike their O1 and O139 counterparts, non O1 and non O139 Vibrio cholera do not produce the cholera toxin. They are hence termed as non-toxigenic [2]. The virulence factors for non-toxigenic Vibrio cholera have not yet been well established. Haemolysin, which would explain the invasive nature of these bacterium appears to be the most likely candidate in these serotypes [3]. Cytotoxic and haemolytic activity has been previously demonstrated in a Non-O1 strain causing bacteraemia in a patient [4]. It has also been postulated that the invasive nature of the bacteria can be attributed to a toxin named the zot toxin which functions by disabling the tight junctions between the epithelial cells of the intestine [5]. Infections in humans arise most commonly due to ingestion of contaminated water and raw or undercooked seafood. Foreign travel to endemic regions and contact of contaminated water with broken skin are also known risk factors. In infants, sterility of artificial feeds and cleanliness of bottles are highly recommended and reinforced by Kerketta et al [6]. In neonates, we may also consider perinatal infections from maternal faecal flora as well as low birth weight ${ }^{5}$ and prematurity [7]. The source of infection in this case could not be ascertained though it is possible the child may have ingested polluted water. As reported previously the disease may present as fever, chills, lethargy, irritability and refusal to feed [8, 9]. Generalized convulsions have also been reported. It is important to note the absence of diarrhoeal disease in both, previous literature as well as this case report.

Antibiotics used in previous case reports, were combination of third generation cephalosporin, PiperacillinTazobactum, Fluoroquinolones and tetracycline's. Early diagnosis and timely antibiotic therapy with adequate duration of treatment may improve the prognosis. Out of 7 case reported cases, we found only 3 survived and these survived with significant neurological sequelae.

\section{References:-}

1. Lan N, Nga T, Yen N, Dung L, Tuyen H, Campbell J et al. Two Cases of Bacteriemia Caused by Nontoxigenic, Non-O1, Non-O139 Vibrio cholerae Isolates in Ho Chi Minh City, Vietnam. J ClinMicrobiol. 2014; 52: 381921.

2. Yang C, Wang C, Lu P, Chen T, Chen Y, Huang M et al. Bullous cellulitis in cirrhotic patients - a rare but life-threatening infection caused by non-O1, non-O139 Vibrio cholera bacteraemia. J Med Microbiol. 2011; 60: $861-2$.

3. Albuquerque A, Cardoso H, Pinheiro D, Macedo G. Vibrio cholerae non-O1 and non-O139 bacteremia in a non-traveler Portuguese cirrhotic patient: First case report. GastroenterolHepatol. 2013; 36: 309-10.

4. Namdari H, Klaips C, Hughes J. A Cytotoxin-Producing Strain of Vibrio cholera Non-O1, Non-O139 as a Cause of Cholera and Bacteraemia after Consumption of Raw Clams. J ClinMicrobiol. 2000; 38: 3518-9.

5. Sarwar S, Hannan A, Sultana Q, Saleem S, Sohail M, Arshad M et al. Non-O1Vibrio choleraebacteraemia in an infant, first case report from Pakistan. J Infect DevCtries. 2016; 10: 188-9.

6. Kerketta J, Paul A, Kirubakaran C, Jesudason M, Moses P. Non-01 Vibrio cholerae septicemia and meningitis in a neonate. Indian J Pediatr. 2002; 69: 909-10.

7. Ismail E, Shafik M, Al-Mutairi G. A Case of Non-O:1 Vibrio cholerae Septicemia with Meningitis, Cerebral Abscess and Unilateral Hydrocephalus in a Preterm Baby. Euro J ClinMicrobiol Infect Dis. 2001; 20: 598-600.

8. Naidu L, Bakerman P, Saubolle M, Lewis K. VIBRIO CHOLERAE non-O: 1 meningitis in an infant. Pediatr Infect Dis J. 1993; 12: 879-81.

9. Mirza Zain Baig, Umme Hani Abdullah,YusraShafquat ,Khadija NuzhatHumayun ,

10. Non O1, non O139 Vibrio cholerae bacteraemia in an infant,JPMA.2018;vol-68, issue-4. 